\title{
DAMPAK KUNJUNGAN WISATAWAN TERHADAP PELESTARIAN MUSEUM TRINIL
}

\author{
TAHUN 2010-2013
}

\section{Yuli Astutik \& Soebijantoro*}

\begin{abstract}
Abstrak
Penelitian ini bertujuan untuk mengetahui dampak kunjungan wisatawan terhadap pelestarian Museum Trinil tahun 2010-2013. Lokasi penelitian ini berada di Musuem Trini dan sekitarnya Dukuh Pilang Desa Kawu Kecamatan Kedunggalar Kabupaten Ngawi. Dalam penelitian ini menggunakan pendekatan induktif dengan jenis penelitian deskriptif kualitatif. Sumber data yang digunakan dalam penelitian ini yaitu sumber datar primer dan sumber data sekunder. Teknik pengumpulan data menggunakan teknik wawancara, observasi dan dokumentasi. Validasi yang digunakan untuk menguji kebenaran dan keabsahan data menggunakan triangulasi sumber. Sedangkan analisis data menggunakan analisi model interaktif miles dan hubbermain. Hasil penelitian yang diperoleh yaitu semakin banyak jumlah wisatawan yang berkunjung ke Museum Trinil yang terjadi pada tahun 2010 hingga 2013 menyebabkan Museum Trinil semakin tidak lestari. Hal ini dibuktikan dengan banyaknya dampak negatif kuat daripada dampak positif. Berdasarkan hasil wawancara dan hasil observasi di lapangan menunjukkan bahwa keinginan dari sebagian besar wisatawan asing untuk memiliki benda-benda cagar budaya yang asli bukan replika buatan manusia sebagai sebuah souvenir. Sehingga hal ini menyebabkan sebagian besar koleksi-koleksi yang ada di Museum Trinil hanya sebuah replika atau tiruan dari fosil yang sebenarnya yang dapat mengurangi keaslian bukti peninggalan sejarah yang ada Kabupaten Ngawi khususnya di Museum Trinil itu sendiri. Sedangkan wisatawan lokal sering meninggalkan sampah disekitar Museum Trinil khususnya di taman belakang yang lokasinya jauh dari pengawasan pengelola museum. Selain itu, banyaknya coretan-coretan menggunakan aerosol semprot benda-benda yang ada di sekitar Museum Trinil. Terbukti dari banyaknya coretan pada replika hewan-hewan purba yang ada di taman belakang gedung serta pada tugu peresmian berdirinya Museum Trinil. Meskipun peningkatan jumlah wisatawan yang terjadi mulai tahun 2010 hingga 2013 membawa dampak positif dengan perenovasian gedung Museum Trinil yang dilakaukan oleh Pemerintah Pusat, dampak negatif akan tetap ada dan kemungkinan juga akan merusak hasil perenovasian tersebut apabila tidak diimbangi dengan peraturan-peratuan yang jelas untuk para wisatawan baik asing maupun lokal.
\end{abstract}

\section{Kata Kunci : Kunjungan Wisatawan, Pelestarian Museum}

\section{Pendahuluan}

Hampir semua orang mengenal dan menyukai apa yang disebut dengan pariwisata. Pariwisata bukan lagi sebuah kegiatan perjalanan yang mewah ditengahtengah masyarakat. Kegiatan tersebut sudah dikenal sejak masa sebelum Revolusi Industri. Tetapi maksud dari perjalanan yang dilakukan pada masa itu bukan untuk rekreasi melainkan untuk keperluankeperluan pragmatis seperti perjalanan dinas, ziarah, dagang dan lain sebagainya (Kodhyat, 1996: 13). Pada zaman dahulu pariwisata hanya dilakukan oleh raja maupun bangsawan saja, tetapi sekarang haltersebut dapat dilakukan oleh siapapun, dimanapun dan kapanpun.Seiring perkembangan zaman, saat ini seseorang melakukan kegiatan pariwisata tidak hanya 
sekedar mencari tahu tentang keberadaan suatu tempat, tetapi sudah merupakan suatu kebutuhan. Hal ini sesuai dengan teori motivasi yang dikemukan oleh Abraham Maslowbahwa manusia selalu terdorong untuk memenuhi kebutuhan yang kuat sesuai waktu, keadaan dan pengalaman yang bersangkutan dengan mengikuti suatu hirearki (Muljadi, 2010: 5). Apabila kita berbicara tentang pariwisata banyak hal yang menarik untuk diperbincangkan terutama di Indonesia, dari Mianas sampai Pulau Rote memiliki keunikan serta kenampakan alam yang menarik sebagai daerah tujuan wisata. Di Indonesia kegiatan pariwisata itu sendiritidakhanya dikenal dalam dasawarsa terakhir ini saja, melainkan kegiatan tersebut di Indonesia sudah terjadi sejak masa kerajaan. Dimana sebagian raja-raja di Indonesia pada masa itu membangun berbagai sarana yang bersifat rekreatif. Diantaranya Taman Narmada yang dibangun pada abad ke-17 sebagai tempat peristirahatan raja-raja Lombok. Selain itu, Kolam Segaran di Trowulan yang dibangun pada masa kejayaan kerajaan Majapahit sebagai tempat rekreasi, disamping untuk penyediaan air pada musim kemarau (Kodhyat, 1996:16).

Kemudian pariwisata di Indonesia mulai lebih berkembang pada masa penjajahan Hindia Belanda. Dimana pada masa ini disamping pemerintah Hindia Belanda mencari rempah-rempah dan memeras sumber daya manusia, mereka juga memanfaatkan keindahan alam yang dimiliki Indonesia untuk menarik para bangsawan dari negara lain melakukan kegiatan pariwisata ke Indonesia. Meskipun demikian kunjungan wisatawan asing di Indonesia cukup terbatas. Pemerintah kolonial membatasi dan mengawasi secara ketat kunjungan dan ruang gerak orangorang asing non-Belanda sebagai upaya agar wisatawan asing tidak terpikat dengan kekayaan alam Indonesia (1996: 46). Sehingga dapat dikatakan bahwa pariwisata yang dikelola pada masa kolonial sebagai penunjang sektor perekonomian mereka. Hal tersebut terjadi sampai sekarang bahwa pariwisata masih memegang peranan penting dalam sektor ekonomi. Devisa yang dihasilkan dari pariwisata mampu menjadi sumber pendapatan nomor tiga setelah komoditi ekspor minyak dan kelapa sawit.

Di Indonesia terdapat banyak sekali tempat-tempat wisata domestik (wisata lokal) yang tidak kalah dengan tempat wisata di luar negeri. Mulai dari wisata alam maupun wisata buatan. Menurut Oka A.Yoeti (2006: 4-8) menjelaskan bahwa objek dan daya tarik wisata berdasarkan Riset Citra Pariwisata (Survey On Indonesia's Tourism Image As Perceived By International Tourists 2003) yang dilakukan oleh Departemen Kebudayaan dan Pariwisata, disimpulkan Objek dan Daya Tarik Wisata (ODTW) merupakan daya tarik yang tidak pernah dilewatkan yang terdiri dari empat kategori yaitu pertama ODTW keindahan 
alam, ODTW berupa peninggalan sejarah, ODTW yang masuk dalam kategori budaya dan ODTW yang diciptakan manusia.

\section{Objek dan Daya Tarik Wisata} tentang keindahan alam merupakan tempat wisata ciptaan Tuhan Yang Maha Esa yang berwujud keadaan alam serta flora dan fauna, seperti pemandangan alam, panorama indah, hutan rimba dengan tumbuhan tropis, serta binatang-binatang langka. ODTW berupa peninggalan sejarah yaitu tempat-tempat yang memiliki peninggalan purbakala, berupa museum maupun semua benda-benda peninggalan bersejarah. ODTW yang masuk dalam kategori budaya adalah objek-objek wisata yang sering menampilkan atraksi-atraksi budaya khas daerahnya. Sedangkan ODTW yang diciptakan manusia merupakan karya manusia yang berwujud bangunan, gedung, tempat rekreasi, taman hiburan, maupun wisata-wisata agro.

Dari penggolongan tempat-tempat wisata yang disebutkan di atas, Ngawi adalah kabupaten yang memiliki tempat wisata dengan kategori kedua yaitu peninggalan sejarah berupa benda-benda purbakala yang tersimpan di museum. Masyarakat lebih mengenal keberadaan museum di Ngawi dengan nama Museum Trinil sebagai tempat pelestarian bendabenda purbakala. Keberadaan Museum Trinil belum mendapat urutan pertama sebagai tujuan wisata dikalangan wisatawan lokal kususnya untuk masyarakat di sekitar
Kabupaten Ngawi itu sendiri. Dewasa ini beberapa museum di Indonesia sebenarnya kaya akan koleksi, namun masih dikatakan miskin informasi. Pengunjung hanya menikmati benda kuno, bukan gagasan, pengetahuan atau pesan yang bermanfaat saat ini (Abraham, 2011: 81).

Berdasarkan catatan lapangan yang dilakukan peneliti dengan Petugas Museum Trinil yang dilakukan pada 13 Oktober 2013 dapat disimpulkan bahwa sampai saat ini ada beberapa koleksi Museum Trinilyang mengalami kerusakan tetapi tidak parah. Sejumlah benda-benda purbakala dan beberapa atau bahkan seluruh koleksi museum hanyalah benda purbakala imitasi atau tidak asli. Dengan adanya fenomena tersebut maka dapat dipastikan tidak ada wisatawan yang tertarik untuk berkunjung ke Museum Trinil. Tetapi berdasarkan data dari loket penjualan tiket masuk museum, terjadi peningkatan jumlah kunjungan wisatawan yang cukup signifikan dari tahun 2010 hingga 2013. Peningkatan kuantitas wisatawan tersebut dimungkinkan akan memberikan dampak bagi Museum Trinil itu sendiri. Berdasarkan keadaan inilah maka penelitian ini dilakukan untuk mengetahui dampak yang ditimbulkanbaik dampak negatif maupun positif terkait dengan jumlah kunjungan wisatawan terhadap pelestarian Museum Trinil sepanjang tahun 2010 hingga 2013 di Kabupaten Ngawi.

\section{Tujuan Penelitian}


Berdasarkan latar belakang masalah, batasan masalah dan rumusan masalah di atas, maka penelitian ini bertujuan untuk menganalisis dan mendeskripsikan dampak kunjungan wisatawan terhadap pelestarian Museum Trinil tahun 2010-2013.

\section{Kajian Pustaka}

\section{A. Pariwisata}

\section{Pengertian Pariwisata}

Secara etimologi kata pariwisata berasal dari dua suku kata yaitu, pari dan wisata. Pari berarti banyak, berkali-kali dan berputar-putar, sedangkan wisata berarti perjalanan atau bepergian. Sehingga pariwisata berarti perjalanan atau bepergian yang dilakukan secara berkali-kaliatau berkeliling (Muljadi, 2010: 8). Pariwisata lebih identik diartikan sebagai kunjungan seseorang atau kelompok ke suatu tempat dengan tujuan menghilangkan penat maupun sekedar tahu tempat tersebut. Pada hakikatnya berpariwisata adalah suatu proses kepergian sementara dari seseorang atau lebih menuju tempat lain di luar tempat tinggalnya (Gamal Suwantoro, 2004: 3). Pengertian tersebut sama seperti yang telah dijelaskan oleh Kodhyat (1996: 1) bahwa pariwisata adalah suatu fonomena yang ditimbulkan oleh salah satu bentuk kegiatan manusia, yaitu kegiatan yang disebut perjalanan (travel). Suatu perjalanan dapat dikatakan sebagai pariwisata apabila memiliki beberapa cirri-ciri diantaranya pertama, adanya unsur travel (perjalanan) yaitu pergerakan manusia dari satu tempat ke tempat lainnya. Kedua, adaya unsur tinggal sementara di tempat yang bukan merupakan tempat tinggal yang biasanya. Ketiga, tujuan utama dari pergerakan manusia tersebut bukan untuk mencari penghidupan/ pekerjaan di tempat yang dituju (Richardson and Fluker dalam I Gde Pitana dan Gayatri, 2005: 46).

Hal senada disampaikan oleh pakar pariwisata berkebangsaan Swiss, Huziker dan Krapf (dalam Muljadi, 2010: 8) mendefinisikan pariwisata sebagai:

The totality of realitionship and phenomena arising from the travel and stay of strangers, provided the stay does not empty establishment permanent residence and is not connected with a remunerated activit. (Penjelasan secara harfiah tersebut menegaskan 
bahwa pariwisata adalah keseluruhan hubungan dan gejala-gejala yang timbul dari adanya orang asing dan perjalanannya itu tidak untuk bertempat tinggal menetap dan tidak ada hubungan dengan kegiatan untuk mencari nafkah).

Muljadi

(2010:

memandang pariwisata adalah suatu aktivitas perubahan tempat tinggal sementara dari seseorang, di luar tempat tinggal sehari-hari dengan suatu alasan apapun selain melakukan kegiatan yang bisa menghasilkan upah atau gaji. Seperti yang terkandung dalam Undangundang No. 10 tahun 2009 Tentang Kepariwisataan Pasal 1 Ayat 3 dijelaskan bahwa pariwisata adalah berbagai macam kegiatan wisata dan didukung berbagai fasilitas serta layanan yang disediakan oleh masyarakat, pengusaha, Pemerintah dan Pemerintah Daerah. Ada pula yang mengatakan bahwa pariwisata merupakan suatu "withdrawal symptom" dimana terdapat suatu gejala orang-orang melarikan diri dari lingkungan yang biasanya mereka tinggali atau dari tempat mereka bekerja sehari-hari dengan tujuan untuk mencari sesuatu yang aneh maupun berbeda dari yang biasanya mereka lihat (Oka A.Yoeti, 1996: 73).

Mathieson and Wall dalam kutipan I Gusti Bagus dan Mahadewi (2012: 104) menyatakan pariwisata adalah perpindahan masyarakat untuk sementara ke suatu destinasi di luar tempat normal mereka tinggal dan bekerja untuk melakukan aktivitas di daerah destinasi dengan adanya fasilitas untuk memenuhi kebutuhannya. Pariwisata juga dapat dipahami sebagai aktivitas bersantai atau aktivitas waktu luang. Perjalanan wisata bukanlah suatu kewajiban, dan umumnya dilakukan pada saat seseorang bebas dari pekerjaan (I Gde Pitana dan Gayatri, 2005: 47). Dengan kata lain, perjalanan pariwisata adalah perjalanan mengisi waktu luang pada saat liburan yang tidak digandulkan dengan keperluan atau maksudmaksud lainnya di balik perjalanan tersebut (Oka A. Yoeti, 1996: 119).

Dari beberapa pendapat mengenai pengertian pariwisata maka dapat disimpulkan bahwa pariwisata adalah suatu kegiatan manusia berpindah tempat atau aktivitas perjalanan untuk sementara waktu dengan tujuan tertentu tanpa ada maksud menetap 
maupun mencari nafkah dimana tempat yang dituju tersebut juga menyediakan fasilitas untuk memenuhi kebutuhan hidupnya.

\section{Pengertian Wisatawan}

Istilah wisatawan lebih ditujukan pada seseorang atau sekelompok orang yang sedang melakukan suatu perjalanan wisata maupun berkunjung ke tempat wisata (Gamal Suwantoro, 2004: 4). Menurut Kamus Besar Bahasa Indonesia wisatawan adalah orang yang berwisata, pelancong, turis, pemerintah berusaha menarik lebih banyak arus luar negeri dengan memperkenalkan tempat-tempat yang indah dan menarik (KBBI, 2007: 1367). Ogilvie (dalam Nyoman, 2006: 35) mendefinisikan wisatawan adalah semua orang yang memenuhi syarat, yaitu pertama, bahwa mereka meninggalkan rumah kediamannya untuk jangka waktu kurang dari satu tahun dan kedua, bahwa sementara mereka bepergian mereka mengeluarkan uang di tempat yang mereka kunjungi tanpa dengan maksud mencari nafkah di tempat tersebut. Wisatawan juga dapat dipahami sebagai seseorang yang pergi meninggalkan rumahnya dengan alasan apapun tanpa memangku jabatan atau pekerjaan di Negara yang dikunjunginya.
Artinya bahwa kepergian seseorang tersebut memiliki alasan tertentu bukan untuk urusan yang berhubungan dengan pekerjaannya (Oka A.Yoeti, 1996: 73). Definisi senada juga disampaikan oleh I Gusti Bagus dan Mahadewi (2012: 105) tentang wisatawan adalah pengunjung sementara yang tinggal sekurang-kurangnya 24 jam di suatu destinasi yang dikunjunginya dengan tujuan untuk bersenangsenang (pleasure), bisnis, keluarga, misi atau pertemuan.

Berdasarkan Undang-undang No.10 Tahun 2009 tentang Kepariwisataan Pasal 1 ayat 2, pengertian wisatawan adalah orang yang melakukan kegiatan wisata, sedang wisata adalah kegiatan perjalanan yang dilakukan oleh seseorang atau sekelompok orang dengan mengunjungi tempat tertentu untuk tujuan rekreasi, pengembangan pribadi, atau mempelajari keunikan daya tarik wisata yang dikunjungi dalam jangka waktu sementara.

I Gde Pitana dan Diarta (2009: 39) merumuskan bahwa seseorang dapat dikatakan sebagai wisatawan dilihat dari sisi perilakunya memiliki kriteria sebagai berikut: 
1) Melakukan perjalanan jauh dari tempat tinggal normalnya sehari-hari;

2) Perjalanan tersebut dilakukan paling sedikit semalam tetapi tidak secara permanen;

3) Dilakukan pada saat tidak bekerja atau mengerjakan tugas rutin lain tetapi dalam rangka mencari pengalaman mengesankan dari interaksinya dengan beberapa karakteristik tempat yang dipilih untuk dikunjungi.

\section{IUOTO (International Union of}

Official Travel Organizations) merupakan organisasi internasional yang berdiri pada tahun 1925 bermarkas besar di Den Haag (Belanda) sebagai organisasi penghimpun badan-badan kepariwisataan negara-negara memberikan rumusan tentang pengertian wisatawan adalah pengunjung sementara yang tinggal sekurang-kurangnya 24 jam di Negara yang dikunjungi, dengan maksud dan tujuan perjalanannya untuk keperluan liburan, kesehatan, studi, agama (ziarah) dan olahraga (Kodhyat, 1996: 4). Adanya tujuan dan maksud yang dibawa oleh masing-masing wisatawan menjadikan kegiatan antara wisatawan satu dengan yang lainnya berbeda-beda. Misalnya, apabila tujuan perjalanan tersebut untuk studi maupun liburan di museum atau tempat penyimpanan purbakala, tidak menuntut kemungkinan benda-benda purbakala bisa jadi rusak atau bahkan hilang. Larangan merusak bagian dari tempat wisata tertuang dalam Undang-undang No.10 tahun 2009 tentang Kepariwisataan pasal 27 ayat 1-2 yang berbunyi,

1) Setiap orang dilarang merusak sebagian atau seluruh fisik daya tarik wisata.

2) Merusak fisik daya tarik wisata sebagaimana dimaksud pada ayat (1) adalah melakukan perbuatan mengubah warna, mengubah bentuk, menghilangkan spesies tertentu, mencemarkan lingkungan, memindahkan, mengambil, menghancurkan, atau memusnahkan daya tarik wisata sehingga berakibat berkurang atau hilangnya keunikan, keindahan, dan nilai autentik suatu daya tarik wisata yang telah ditetapkan oleh Pemerintah dan/atau Pemerintah Daerah.

Meskipun demikian, kebijakan tersebut dirasa masih nihil. Terbukti dari sebagian besar fasilitas-fasilitas yang ada di tempat wisata rusak dan 
tercemar akibat ulah wisatawan. Dari penjelasan di atas dapat disimpulkan bahwa wisatawan adalah seseorang maupun sekelompok orang yang pergi berkunjung ke suatu tempat wisata baik dalam negeri maupun luar negeri dengan tujuan tertentu dalam waktu sekurang-kurangnya 24 jam tanpa ada maksud mencari nafkah di tempat tersebut.

\section{Tipologi Wisatawan}

Tidak hanya tempat-tempat wisata saja yang dapat diklasifikasikan jenisnya, dalam pariwisata tipologi wisatawan juga dapat diklasifikasikan dengan menggunakan berbagai dasar. Pada prinsipnya dasar-dasar klasifikasi tersebut dapat dikelompokkan menjadi dua, yaitu atas dasar interaksi (interactional type) dan atas dasar kognitif-normatif (Murphy dalam I Gde Pitana dan Gayatri, 2005: 53). Dimana tipologi atas dasar interaksi dilihat dari seberapa jauh interaksi antara wisatawan dengan masyarakat lokal. Dengan adanya interaksi tersebut menandakan bahwa masyarakat lokal menerima baik kedatangan wisatawan. Sedangkan tipologi atas dasar kognitif-normatif menekankan pada motivasi yang melatarbelakangi perjalanan.
Motivasi perjalanan antara wisatawan satu dengan wisatawan yang lainnya tentu berbeda-beda. Oka A.Yoeti (1994: 7) merumuskan motivasi wisatawan melakukan perjalanan wisata diantaranya untuk tujuan santai dan kesegaran badan, tujuan kesehatan, mencari kesenangan, menaruh perhatian terhadap Negara lain, alasan untuk mengunjungi famili, untuk mencari hal-hal yang bersifat spiritual, dan keinginan untuk mengetahui lebih mendalam tata cara hidup di tempat yang dikunjunginya. Adakalanya motivasi seseorang melakukan perjalanan pariwisata yaitu sebagai salah satu cara untuk menemukan diri sendiri yang dapat menunjukkan atau memberikan petunjuk siapa “aku” ini sesungguhnya (2006: 179).

Berangkat dari motivasi yang dimiliki oleh masing-masing wisatawan tersebut maka obejk wisata yang dipilih juga harus tepat. Museum merupakan salah satu tujuan wisata yang mencakup tiga hal pokok terkait dengan kebutuhan pengunjung, yakni sebagai tempat riset, pendidikan dan hiburan. Tujuan pendirian museum sebagai tempat riset diperuntukkan bagi akademisi yang melaukan penelitian. Kedua, museum sebagai sarana edukasi dimana semua orang dapat 
mengetahui informasi yang ada di museum maupun dapat mengamati benda dan pola-pola tertentu yang disajikan dalam museum. Ketiga, museum sebagai tempat hiburan atau tempat rekreasi dimana seseorang dapat menikmati libur, santai dan penyegaran badan maupun pikiran dari kegiatan kesehariannya (Supratikno, 2011: 162-163).

\section{B. Museum}

\section{Pengertian dan Fungsi Museum}

Secara umum museum dapat dipahami sebagai tempat untuk menyimpan atau mengoleksi benda-benda yang dianggap langka maupun bendabenda hasil temuan yang dinilai mempunyai arti dan makna bagi perkembangan budaya atau ilmu pengetahuan (Mohammad Iskandar, 2009: 103). Menurut Parker yang dikutip dalam Abraham Nurcahyo dan Yudi Hartono (2011: 69) menerangkan bahwa museum adalah suatu lembaga yang aktifitasnya mengabdikan diri pada tugas interpretasi dunia manusia dan lingkungannya. Pengertian yang sama diungkapkan oleh Soenatris (2001: 5) tentang istilah museum berasal dari bahasa Yunani, yaitu Musion yang berarti sebuah bangunan tempat suci untuk memuja dewa seni dan dewa ilmu pengetahuan yang terletak di gunung Parnanus.

Adapun Peraturan Pemerintah No.19 Tahun 1995 Tentang Pemeliharaan dan Pemanfaatan Benda Cagar Budaya di Museum pasal 1 ayat 1 bahwa museum merupakan lembaga tempat penyimpanan, perawatan, pengamanan dan pemanfaatan benda-benda bukti material hasil budaya manusia serta alam dan lingkungannya, guna menunjang upaya perlindungan dan pelestarian kekayaan budaya bangsa.

Dalam Jurnal Kebudayaan Vol.2 (2012: 234) pengertian museum menurut definisi International Council of Museum (ICOM) sebagai berikut:

A museum is a non profit permanent institution, in the service of society and its development and open the public, which acquires, concerves, researches, communicates and exhibits, for the purpose of study, education and 
enjoyment, material of

man and his environment.

(Museum adalah sebuah

lembaga tetap yang tidak

mencari keuntungan

pribadi belaka, melayani

masyarakat dan

perkembangannya,

terbuka untuk umum

yang memperoleh,

merawat,

menghubungkan dan

memerkan untuk tujuan

studi, pendidikan, dan

kesenangan (kepuasan

batin), barang-barang

pembuktian manusia dan

lingkungannya).

Museum sebagai suatu lembaga tetap juga berhak merawat dan melindungi serta memamerkan koleksi bendabenda sejarah, maka museum memiliki beberapa fungsi. Menurut Oka A.Yoeti (2006: 14), terdapat dua fungsi museum yaitu pertama melindungi dan menjaga kelestarian bendabenda bukti material hasil budaya manusia serta alam dan lingkungannya.

Kedua, mengkomunikasikan dan menyebarkan informasi mengenai benda-benda tersebut kepada masyarakat melalui publikasi, bimbingan edukatif cultural dan pameran.

Hal serupa juga disampaikan oleh Mohammad Iskandar (2009: 103) bahwa koleksi yang tersimpan dalam museum, selain untuk penyelamatan maupun objek penelitian kepurbakalaan atau arkeologis, juga berfungsi untuk memperkenalkan peninggalanpeninggalan budaya Indonesia. Hal senada juga dijelaskan dalam Undang-undang No.11 Tahun 2010 Tantang Cagar Budaya Pasal 18 ayat 2, museum merupakan lembaga yang berfungsi melindungi, mengembangkan, memanfaatkan koleksi berupa benda, bangunan dan/atau struktur yang telah ditetapkan sebagai cagar budaya atau yang bukan cagar budaya, dan mengakumulasikannya kepada masyarakat.

Berdasarkan beberapa pengertian di atas maka dapat dijelaskan mengenai pengertian museum yaitu suatu tempat penyimpanan dan pelestarian benda-benda cagar budaya sebagai sarana edukasi maupun sarana informasi kepada 
masyarakat luas. Dimana sebuah museum selain berfungsi sebagai obyek penelitian kepurbakalaan maupun arkeolgi, museum juga berfungsi untuk memperkenalkan peninggalanpeninggalan budaya Indonesia kepada masyarakat Indonesia pada kususnya dan dimata dunia pada umumnya.

\section{Jenis Museum}

Banyaknya peninggalanpeninggalan budaya yang ada di Indonesia menjadikan Indonesia memiliki banyak museum yang tersebar di seluruh Nusantara. Urip Suroso (1993: 26) menerangkan bahwa terdapat bermacam-macam museum yang dapat ditinjau dari berbagai sudut pandang, diantaranya jenis museum menurut koleksinya dikelompokkan menjadi dua jenis yaitu:

1) Museum Umum, yaitu museum yang koleksinya terdiri atas kumpulan bukti material manusia atau lingkungannya yang berkaitan dengan berbagai cabang seni, disiplin ilmu dan teknologi.
2) Museum Khusus, yaitu museum yang koleksinya terdiri dari kumpulan bukti material manusia atau lingkungannya yang berkaitan dengan satu cabang seni, satu cabang ilmu atau suatu cabang teknologi.

Dari penggolongan jenis museum di atas, maka dapat dikatakan Museum Trinil masuk pada kategori jenis museum khusus. Hal ini terbukti dari koleksi-koleksi yang ada di Museum Trinil hanya satu jenis saja yang berkaitan dengan dengan satu cabang seni maupun cabang ilmu yaitu kepurbakalaan. Dimana koleksi Museum Trinil terdiri dari fosil manusia purba, fosil hewan purba seperti gajah, kerbau, badak kuda nil purba, fosil kerang dan tumbuhan serta replika manusia purba (Soenatris Hadi, 2001: 3).

Sedangkan jenis museum menurut kedudukannya antara lain yaitu Museum Nasional, Museum Provinsi dan Museum Lokal. Museum Nasional adalah museum yang koleksinya bersal dari seluruh wilayah Indonesia 
yang bernilai nasional. Museum Provinsi yaitu museum yang koleksinya yang mencerminkan atau menggambarkan wilayah provinsi dimana museum tersebut berada. Museum Lokal merupakan museum yang koleksinya berasal dari wilayah kabupaten atau kotamadya (Urip Suroso, 1993: 26).

Menurut

penyelenggaraanya, museum dibedakan atas Museum Pemerintah dan Museum Swasta. Dimana Museum Pemerintah merupakan museum yang diselenggarakan dan dikelola oleh pemerintah, baik pemerintah pusat maupun pemerintah daerah. Museum Swasta yakni museum yang diselenggarakan serta dikelola oleh pihak swasta (1993: 27). Dari penggolongan jenis museum tersebut, museummuseum yang ada di Indonesia yang dikelola oleh pihak swasta lebih maju daripada museum yang dikelola oleh pemerintah. Hal ini terbukti dari sejumlah museum pemerintah yang lambat laun semakin kusam dan tidak menarik lagi. Sehingga menimbulkan kesan pada masyarakat bahwa museum hanyalah sebuah bangunan penyimpanan benda-benda kuno. Keadaan tersebut yang akan mempengaruhi intensitas pengunjung untuk berwisata ke museum baik pengunjung dari golongan pelajar maupun umum. Ada yang mengatakan bahwa museum akan tetap berdiri selama ada pengunjungnya. Artinya kelangsungan hidup museum tergantung pada banyak atau tidaknya pengunjung museum yang datang. Tetapi di sisi lain kuantitas pengunjung tersebut bukan berarti menjadi satusatunya faktor pelestarian museum. Sebab terdapat beberapa museum dengan jumlah pengunjung yang banyak malah membuat museum tersebut menjadi tidak lestari. Misalnya benda-benda koleksi museum sebagian mengalami kerusakan atau imitasi. Berbeda dengan museum swasta yang senantiasa memberikan warna baru dalam pengelolaan museumnya. Sebagai contoh museum Jamu yang ada di Tawangmangu dengan tatanan yang lebih apik dan unik menjadikan pengunjung lupa akan citra museum sebagai 
tempat yang using. Harapannya dengan berkunjungan ke museum menjadi upaya untuk melestarikan museum tersebut, tidak hanya sebagai hiburan saja tetapi juga sebagai tempat belajar (Harian Kompas, 3 Juli 2013).

\begin{tabular}{lr}
\multicolumn{1}{c}{ Berdasarkan } & jenis \\
museum & menurut \\
penyelenggaraannya, & Museum \\
Trinil merupakan jenis museum \\
pemerintah. Hal ini dapat dilihat \\
dari pengelolaan Museum Trinil \\
dibawah pembinaan \\
DISPARYAPURA
\end{tabular}

Pariwisata Budaya Pemuda dan Olahraga) Kabupaten Ngawi mulai dari pengelolaan infrastruktur jalan menuju museum hingga semua fasilitas yang ada di museum (wawancara dengan Sujono 13 Oktober 2013).

$$
\text { Adapun dalam }
$$

Ensiklopedia Nasional Indonesia (1990: 105-106) jenis museum berdasarkan ruang lingkup wilayah tugasnya dan status hukum pendirian dan tujuan penyelenggaraannya, terbagi menjadi tiga yaitu Museum Nasional, Museum Lokal dan Museum Lapangan Terbuka. Museum Nasional adalah museum yang menjadi urusan pemerintah, sedangkan koleksinya menggambarkan harta warisan sejarah alam atau sejarah kebudayaan nasional. Museum Lokal yaitu museum yang ruang lingkup tugasnya terbagi atas lingkup provinsi, kabupaten dan kota madya. Sedangkan Museum Lapangan Terbuka ialah museum dengan lahan yang luas dan terdiri dari beberapa jenis bangunan maupun koleksi. Museum Lapangan Terbuka dapat pula terdiri atas Museum Situs, yakni museum yang didirikan di lahan dekat kompleks bangunan bersejarah atau bekas peninggalan kepurbakalaan.

\section{Museum Trinil}

Dalam catatan Soenatris Hadi (2001: 1), Museum Trinil merupakan salah satu tempat hunian kehidupan purba pada zaman Pleistosen tengah \pm 1 juta tahun yang lalu. Selain ditemukan data manusia purba, di Trinil juga menyimpan bukti konkrit tentang lingkungannya baik flora maupun faunanya.

Soenatris juga mengemukakan asal-usul kata Trinil yaitu Penggalian manusia purba (Pithecanthropus Erectus) 
di tiga perbatasan desa ditengah bengawan Solo, yaitu sebelah barat desa Kawu, sebelah utara desa Gemarang dan sebelah timur desa Ngancar. Selain itu juga Eugene Dubois menggunakan kata Trinil untuk menyebut kode penemuan, dan akhirnya menjadi nama “Museum Trinil” (2001: 24-25).

Museum Trinil berdiri sekitar tahun 1980-1981 dimana pendirian museum ini pada awalnya dirintis oleh salah seorang penduduk setempat bernama Wirodiharjo pada tahun 1968. Mulai didata koleksinya tahun 1979 dengan semakin banyak ditemukan fosil-fosil purba baik oleh para arkelog maupun warga sekitar. Kemudian pembangunan Museum Trinil diresmikan oleh Soelarso Kepala Daerah Tingkat I Jawa Timur pada tanggal 20 November 1991 (Soenatris Hadi, 2001: 2).

Berdasarkan uraian di atas maka dapat disimpulkan tentang pengertian Museum Trinil adalah suatu gedung yang menyimpan, memelihara, merawat serta memamerkan benda-benda sejarah berupa benda-benda purbakala terletak di Kabupaten Ngawi. Disamping berfungsi sebagai tempat penyimpanan benda-benda purbakala untuk sarana edukasi, Museum Trinil juga digunakan sebagai tempat rekreasi.

\section{Metode Penelitian}

\section{A. Lokasi dan Waktu Penelitian}

\section{Lokasi Penelitian}

Lokasi penelitian dilaksanakan di Museum Trinil yang terletak di Dukuh Pilang Desa Kawu Kecamatan Kedunggalar Kabupaten Ngawi. Alasan penelitin ini dilakukan di tempat tersebut yakni Museum Trinil merupakan salah satu tempat wisata budaya di Jawa Timur kususnya di Kabupaten Ngawi yang masih berdiri sampai sekarang sebagai tempat wisata edukasi maupun sebagai tempat pelestarian benda-benda purbakala meskipun terdapat banyak tempat wisata modern yang mulai bermunculan di Kabupaten Ngawi. Museum Trinil berjarak $\pm 14 \mathrm{~km}$ dari Kota Ngawi kearah barat daya pada $\mathrm{Km} 11$ jalan Raya jurusan Ngawi-Solo masuk ke utara $3 \mathrm{Km}$

\section{Waktu Penelitian}

$$
\text { Penelitian ini dilakukan }
$$
selama 6 bulan yaitu mulai bulan Februari sampai Juli 2014. Waktu 
penelitian terbagi dalam tiga tahap yaitu tahap persiapan, tahap penelitian dan tahap penyelesaian. Adapun jadwal penelitian yang dilakukan terdapat dalam pembahasan tahap penyelesaian.

\section{B. Pendekatan dan Jenis Penelitian}

Jenis penelitian ini adalah deskriptif kualitatif. Hal ini didasarkan pada hasil yang dipaparkan dalam penelitian ini berupa penggambarkan situasi yang ada di Museum Trinil tahun 2010-2013. Penelitian deskriptif dapat diartikan sebagai prosedur pemecahan masalah yang diselidiki dengan menggambarkan atau melukiskan keadaan subyek atau objek penelitian pada saat sekarang berdasarkan fakta-fakta yang tampak (Hadari Nawawi, 2005: 63). Hal serupa disampaikan oleh I Made Wirartha (2006: 154) bahwa penelitian deskriptif berkaitan dengan pengumpulan data untuk memberikan gambaran atau penegasan suatu konsep atau gejala. Ditambah analisis data yang dilakukan tidak untuk menerima atau menolak hipotesis, melainkan berupa deskripsi atas gejala yang diamati yang tidak selalu berbentuk angka-angka atau koefisien antar variable (2006: 135).

Sedangkan maksud dari kualitatif adalah metode penelitian yang digunakan untuk meneliti pada kondisi obyek yang alamiah, dimana peneliti adalah sebagai instrumen kunci, teknik pengumpulan data dilakukan secara triangulasi, analisis data bersifat induktif, dan hasil penelitian kualitatif menekankan pada makna (Sugiyono, 2013: 15). Pada dasarnya penelitian kualitatif digunakan dalam penelitian yang merujuk pada obyek dan fenomena yang terjadi secara alami. Selain itu, metode kualitatif digunakan karena metode ini menyajikan secara langsung hakikat hubungan antara peneliti dan informan (Lexy J. Moleong, 2012: 9-10). Sehingga sudah memperjelas alasan bahwa jenis penelitian ini adalah penelitian deskriptif kualitatif.

\section{Sumber Data}

Sumber data pada penelitian ini merupakan subyek dari data yang akan diperoleh. Subyek penelitian adalah informan yang dapat menjelaskan informasi yang diperlukan dalam penelitian. Sumber data pada penelitian ini diperoleh dari sumber data primer dan sumber data sekunder sesuai yang diungkapkan oleh Gabriel Amin Silalahi (2003: 56-57) bahwa sumber data dalam penelitian terbagi menjadi dua yaitu sumber data primer dan sumber data sekunder.

\section{a) Sumber Data Primer}

Sumber data primer merupakan sumber data yang diperoleh secara 
langsung dari sumber asli atau tidak melalui perantara. Data primer adalah data yang diperoleh secara langsung dari masyarakat baik yang dilakukan melalui wawancara, observasi dan alat lainnya (Joko Subagyo, 2004: 87). Menurut Gabriel Amin Silalahi (2003: 57) data-data primer dapat berupa opini informan utama, hasil observasi terhadap suatu benda fisik maupun hasil pengujian. Hal serupa disampaikan oleh Husein Umar (2011:42) data primer merupakan data yang diperoleh dari sumber pertama baik dari individu atau perseorangan seperti hasil dari wawancara atau hasil pengisian kuisioner yang biasa dilakukan oleh peneliti.

Dalam penelitian ini sumber data primer tersebut diperoleh dari informan yang terdiri dari Perangkat Desa, Sesepuh, warga desa sekitar Trinil, pengunjung Museum Trinil, Petugas Museum Trinil dan Dinas Pariwisata Kebudayaan Pemuda dan Olahraga Kabupaten Ngawi.

\section{b) Sumber Data Sekunder}

Sumber data sekunder adalah data penelitian yang diperoleh peneliti secara tidak langsung atau melalui media perantara yang diperoleh maupun dicatat oleh pihak lain (Gabriel Amin, 2003: 57). Adapun sumber data sekunder yang digunakan dalam penelitian ini adalah profil Kabupaten
Ngawi, data yang diperoleh dari DISPARIYAPURA (Dinas Pariwisata Budaya Pemuda dan Olahraga) berupa sumber data tertulis berasal dari arsip, dokumen serta buku-buku yang diperoleh dari Museum Trinil maupun dokumen pribadi milik informan.

\section{Teknik Pengumpulan Data}

Pengumpulan data merupakan prosedur yang sistematik dengan memperhatikan penggarisan yang telah ditentukan. Hal ini dimaksudkan untuk menghindari data yang tidak terpakai karena jauhnya informasi yang diperoleh dengan keperluannya (Joko Subagyo, 2004: 38). Semua kegiatan pengumpulan data dilakukan untuk memecahkan masalah dalam sebuah penelitian. Sesuai dengan pendekatan penelitian kualitatif dan sumber data yang digunakan, maka teknik pengumpulan data dalam penelitian ini menggunakan beberapa teknik, yaitu:

\section{Wawancara}

Wawancara merupakan kegiatan atau metode pengumpulan data yang dilakukan dengan bertatapan langsung dengan informan. Informan yang digunakan dalam penelitian ini baik dari DISPARIYAPURA (Dinas Pariwisata Budaya Pemuda dan Olahraga) Kabupaten Ngawi, penjaga museum Trinil maupun wisatawan dari berbagai tingkatan yaitu tingkatan anak-anak Sekolah Dasar, tingkatan 
anak-anak Sekolah Menengah Pertama maupun Sekolah Menengah Atas, serta tingkatan untuk umum. Dimana pada tingkatan umum ini nantinya diklasifikasikan berdasarkan usia para informan maupun berdasarkan pekerjaan.

Peneliti menggunakan metode wawancara untuk memperoleh data dan informasi yang sifatnya primer dengan mengajukan pertanyaan langsung dan terbuka kepada informan. Untuk itu dalam setiap kegiatan wawancara harus memahami tujuan dari penelitian. Dengan begitu pewawancara selalu terikat dengan tujuan yang ingin dicapai, termasuk juga akan mampu mengembangkan tema-tema wawancara (Burhan Bungin, 2007: 109). Misalnya pertanyaan yang ditujukan kepada penjaga Museum Trinil tentang tindakan pihak museum apabila terjadi kerusakan pada bendabenda purbakala.

\section{Observasi}

Terdapat berbagai jenis observasi, yaitu observasi partisipan, observasi nonpartisipan, observasi eksperimental, observasi noneksperimental, observasi sistematik, dan observasi nonsistematik (Hadari Nawawi, 2005: 104-110). Berdasarkan pengklasifikasian tersebut, observasi dalam penelitian ini dilakukan secara non-partisipan.
Artinya bahwa peneliti tidak ikut di dalam kehidupan orang yang diobservasi dan secara terpisah berkedudukan selaku pengamat. Dengan kata lain, penelitian dilakukan secara sepintas pada saat tertentu (Joko Subagyo, 2004: 66).

\section{Dokumentasi}

Metode dokumentasi digunakan untuk mengumpulkan data yang menghasilkan catatan-catatan penting yang berhubungan dengan masalah yang diteliti. Sehingga akan diperoleh data yang lengkap, sah dan bukan berdasarkan perkiraan (Basrowi Suwandi, 2008: 158). Dalam penelitian ini dokumentasi yang digunakan berupa foto-foto dokumenter koleksi Museum Trinil, catatan pribadi para informan seperti catatan pribadi milik penjaga Museum Trinil dari awal berdirinya sampai sekarang, arsip-arsip dari Dinas Pariwisata Kebudayaan Pemuda dan Olahraga Kabupaten Ngawi terkait dengan kunjungan wisatawan dari tahun 2010-2013. Data dokumentasi ini digunakan sebagai data pendukung, pelengkap dan penguat bagi data primer yang sudah diperoleh.

\section{E. Teknik Keabsahan Data}

Terdapat banyak cara yang bisa digunakan untuk menguji keabsahan data dalam penelitian kualitatif. Lexy J. Moleong (2012: 327) mengungkapkan 
keabsahan data dapat diuji dengan kriteria kredibilitas atau derajat kepercayaan. Kredibilitas data ini dimaksudkan untuk membuktikan bahwa data yang sudah dikumpulkan sesuai dengan kenyataan yang ada di tempat penelitian. Selain itu, dalam penelitian kualitatif terdapat beberapa cara yang bisa dipilih untuk pengembangan validitas (kesahihan) data penelitian. Salah satu diantaranya adalah triangulasi yang diartikan sebagai teknik pengumpulan data yang bersifat menggabungkan dari berbagai teknik pengumpulan data dan sumber data yang telah ada (Sugiyono, 2006: 330).

Pengumpulan data umumnya dilakukan dengan menggunakan triangulasi sumber. triangulasi sumber merupakan cara mengarahkan peneliti agar dalam mengumpulkan data wajib menggunakan beragam sumber data yang tersedia dan berbeda-beda, dengan demikian data yang diperoleh dari sumber satu akan lebih teruji kebenaranya apabila dibandingkan dengan sejenis yang berbeda sumbernya (H.B Sutopo, 2006: 93).

Teknik triangulasi sumber menekankan pada proses pencarian, pengecekan data dari sumber data dengan membandingkan dari berbagai sumber namun dalam pokok permasalahan sama sehingga teknik pengumpulan data dapat teruji kebenaran dan kemantapannya. Adapun secara singkat teknik trianggulasi sumber dapat dilihat dari bagan di bawah ini:

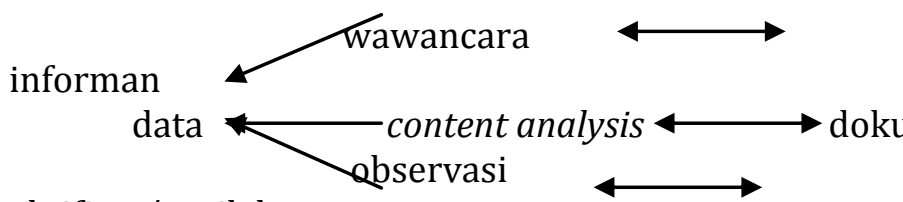
aktifitas/perilaku

Bagan 3.1 : Triangulasi Sumber (H.B Sutopo, 2006: 94)

Teknik triangulasi sumber data dapat dilakukan dengan cara menggali sumber-sumber data yang berbeda jenisnya, seperti menggunakan sumber dari informan. Dalam hal ini diambil dari wawancara dengan Petugas Pemeliharaan Museum Trinil, Dinas Pariwisata Budaya Pemuda dan Olahraga, serta para wisatawan Museum Trinil. Selain itu sumber data juga diambil dari arsip atau dokumen maupun observasi terhadap objek kajian yang diteliti.

\section{F. Teknik Analisis Data}

Analisa data merupakan proses mencari dan menyusun data yang diperoleh dengan mengorganisasikannya kedalam kategori yang telah ditentukan. Menurut Milles and Hubberman (1992: 16) analisis data terdiri dari tiga alur kegiatan yang terjadi secara bersamaan 
yaitu: reduksi data, penyajian data, penarikan kesimpulan/verifikasi.

\section{Reduksi data}

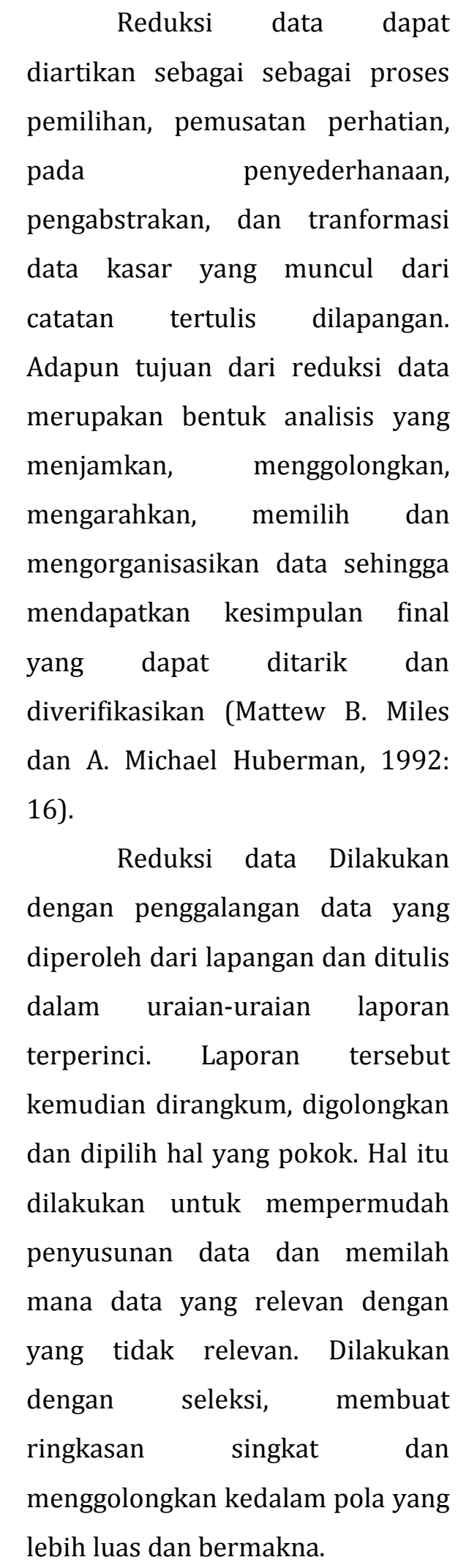

2. Penyajian data (display data)

Penyajian data merupakan sekumpulan informasi tersusun yang memberi kemungkinan adanya penarikan kesimpulan dan pengambilan tindakan (Mattew B. Miles dan A. Michael Huberman, 1998: 17). Data yang telah dipilih kemudian disusun sesuai kategori sejenis untuk ditampilkan sesuai permasalahan yang dihadapi, termasuk kesimpulan sementara yang ditarik saat data direduksi. Ini penting dilakukan karena peneliti harus dapat menggabungkan dan menyusun data yang diperoleh secara baik agar mampu mendapatkan kesimpulan yang benar. Dengan demikian akan memberikan kemudahan untuk melakukan analisis data selanjutya. Saaat melakukan analisis data meliputi kegiatan penyajian data dari data yang diperoleh dilapangan. Peneliti haruslah menyajikan data sevara teliti dan tersusun untuk kemudian dapat menarik kesimpulan dalam tahap yang selanjutnya. wujud sajian data berupa sekumpulan informasi yang disusun sesuai dengan rumusan masalah yang diajukan.

\section{Penarikan \\ kesimpulan (verifikasi)}


Penarikan kesimpulan merupakan tahapan mencari pola dan kejelasan dari informasi yang didapat saat proses penelitian. Hasil kesimpulan akhir diharapkan mampu menjawab permasalahan dalam penelitian. Proses ini merupakan tahapan mencari makna dari data yang diperoleh dan menguji kebenaran serta validitasnya. Verifikasi dilakukan saat data sudah tersusun dan memiliki keterkaitan dengan data yang lain sehingga memiliki relevansi untuk mendukung penelitian.

Kesimpulan-kesimpulan

yang disusun juga diverifikasi selama penelitian berlangsung. Verifikasi yang dilakukan ada kemungkinan merupakan hasil pemikiran sementara yang dimiliki oleh peneliti (Miles \& Huberman, 1998: 19). Untuk itu perlu adanya peninjauan ulang terhadap verifikasi yang dilakukan peneliti agar hasil penarikan kesimpulan lebih benar dan mewakili penelitian yang sebenarnya.

Hasil Penelitian

\section{A. Gambaran Umum Museum Trinil}

\section{Struktur}

Kepengurusan

\section{Museum Trinil}

Setelah adanya verifikasi maka akan di cross check sejumlah data yang terkumpul agar data yang diperoleh benar-benar valid. Data dalam penelitian ini berupa data temuan di lapangan ketika melakukan wawancara dengan informan, dokumen Museum Trinil dan DISPARIYAPURA (Dinas Pariwisata Budaya Pemuda dan Olahraga) Kabupaten Ngawi. Pengecekan data dilakukan dengan membandingkan data semua hasil wawancara, data hasil observasi dan data yang diperoleh dari dokumen dinas terkait. Oleh karena itu dalam tahapan yang dilakukan merupakan suatu rangkaian tahapan yang memiliki keterkaitan. Adapun keterkaitan komponen antara tahapan tersebut sebagai berikut:

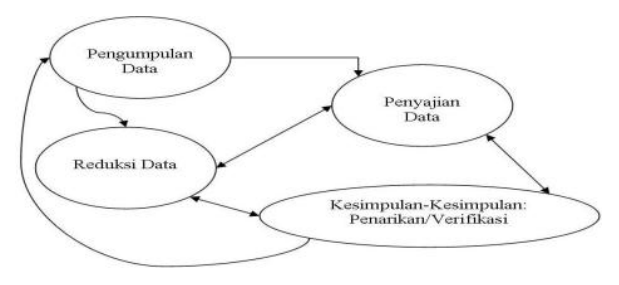

Gambar 3.2

Analisis Data Model Interaktif (Miles dan Huberman, 1992: 20)

Museum Trinil merupakan salah satu museum yang masuk dalam kategori jenis museum lokal dimana ruang 
lingkup tugasnya terbagi atas provinsi dan juga kabupaten. Sehingga untuk kepengurusan Museum Trinil tersebut juga berasal dari dua golongan atau kelompok, yaitu pengelola museum dari Pemerintah Kabupaten Ngawi dan pengurus dari Balai Pelestarian Cagar Budaya Trowulan Mojokerto Jawa Timur. Berikut ini adalah daftar pengelola Museum Trinil:

a. Pengelola dari Balai Pelestarian Cagar Budaya Trowulan

1) Catur Hari Gumono (Pengelola Museum Trinil)

2) Agus H.W (Pengelola Museum Trinil)

3) Mardi (Pengelola Museum Trinil)

4) Sugianto (Pengelola Museum Trinil)

5) Suwardi (Pengelola Museum Trinil)

6) Juwono (Pengelola Museum Trinil)

7) Suwono (Pengelola Museum Trinil)

8) Yayuk S. (Pengelola Museum Trinil)

9) Nanik Limawati (Pengelola Museum Trinil)
10) Sri Wardayati

(Pengelola Museum Trinil)

b. Pengelola dari Pemerintah Kabupaten Ngawi

1) Martha Karuniawati (Kepala Museum Trinil)

2) Sujono (Pengelola Museum Trinil)

3) Suyono (Pengelola Museum Trinil)

4) Suryono (Pengelola Museum Trinil)

5) Suprapto (Pengelola Museum Trinil)

6) Sulistyo Budi (Pengelola Museum Trinil)

Dari paparan tersebut nampak Museum Trinil merupakan museum lokal yang terbagi ke dalam museum provinsi dan museum kabupaten, maka dalam pengelolaan Museum Trinil tersebut juga terbagi dua yaitu pengelolaan dari pihak Pemerintah Kabupaten Ngawi dan pengelolaan dari BPCB (Badan Pelestarian Cagar Budaya) Trowulan. Pemerintah Kabupaten Ngawi lebih cenderung mengelola dalam hal sarana prasarana, seperti penataan taman bermain 
maupun area parkir kendaraan

di museum. Sedangkan dari

Balai Pelestarian Cagar Budaya

Trowulan Mojokerto Jawa

Timur, dalam pengelolaan

Museum Trinil lebih difokuskan

pada koleksi-koleksi yang tersimpan di museum baik koleksi yang dipamerkan maupun koleksi yang masih berada di laboratorium (sumber: daftar pengelola Museum Trinil 2014)

\section{Koleksi Museum Trinil}

Apabila dilihat dari jenis museum yang ada di Indonesia, museum Trinil tergolong dalam museum khusus yaitu koleksikoleksi yang ada di Museum Trinil hanya satu jenis saja yang berkaitan dengan dengan satu cabang seni maupun cabang ilmu yaitu kepurbakalaan. Jumlah koleksi yang ada di Museum Trinil \pm 131 fosil purba yang terdiri fosil manusia purba, fosil binatang purba dan fosil tumbuhan purba, sedangkan yang ada di laboratorium \pm 1000 fosil purba. Koleksi yang dimiliki Museum Trinil terdiri dari fosil manusia purba diantaranya:

a. Fosil gigi geraham manusia purba Pithecanthropus Erectus b. Fosil tengkorak manusia purba Pithecanthropus Erectus

c. Fosil tulang paha manusia purba Pithecanthropus Erectus

d. Fosil atap tengkorak manusia purba Pithecanthropus Erectus

e. Fosil tengkorak manusia purba Pithecanthropus Soloensis

Sedangkan koleksi fosil hewan purba yang ada di ruang pameran Museum Trinil maupun yang ada di laboratorium diantaranya fosil gajah purba atau fosil gading purba, fosil kerbau purba, badak kuda nil purba, fosil kerang dan tumbuhan purba (wawancara WR-02, 27 April 2014).

\section{Sejarah Museum Trinil}

Menurut WR-02 kata Trinil diartikan sebagai penggalian manusia purba (Pithecanthropus Erectus) di tiga perbatasan desa ditengah bengawan Solo, yaitu sebelah barat desa Kawu, sebelah utara desa Gemarang dan sebelah timur desa Ngancar. Selain itu, Eugene Dubois menggunakan kata Trinil untuk menyebut kode penemuan, dan akhirnya 
menjadi nama "Museum Trinil". Pendirian museum ini dirintis oleh salah seorang penduduk setempat bernama

Wirodihardjo pada tahun 1968 (wawancara 27 April 2014).

Wirodihardjo atau Wiro Balung lahir pada tanggal 18 Agustus 1918 di Desa Gemarang Kecamatan Kedunggalar Kabupaten Ngawi. Penyebutan nama Wiro Balung itu melakat dikarenakan Wirodihardjo suka mengumpulkan balung atau tulang dalam hal ini yang dimaksudkan adalah fosil-fosil yang telah ditemukan. Pada tahun 1930 Wirodihardjo lulus dari Sekolah Rakyat atau SR. Kemudian melanjutkan ke Gubernemen pada masa penjajahan Belanda dan lulus tahun 1932. Pada tahun 1941 Wirodihardjo menjadi BKR (Barisan Keamanan Rakyat) di desa dan masuk menjadi pasukan Seinedan pada tahun 1942 ketika Indonesia masa penjajahan Jepang. Setelah Indonesia merdeka Wirodihardjo menjadi hansip, sedangkan pada tahun 19651967 diangkat menjadi Bayan Desa Kawu.
Sesudah menjabat sebagai Bayan, Wiro menjadi petani biasa. Ditengah-tengah kesibukannya menjadi petani tersebut, Wiro menjadi tenaga pembantu ekspedisi penelitian Eugene Dubois dan Salenka ilmuan asal Belanda. Berbekal dari pengalaman tersebut Wiro mulai gemar mengumpulkan fosil-fosil disekitar tepian sungai Bengawan Solo yang arah alirannya melalui Dukuh Pilang Desa Kawu dimana penemuan fosil yang Wiro lakukan tersebut secara tidak sengaja. Kemudian fosil yang Wiro temukan pada saat itu diteliti oleh Eugene Dubois dan Salenka. Ternyata fosil-fosil tersebut merupakan salah satu jenis fosil Pithecanthropus Erectus. Penemuan tersebut mengundang banyak perhatian masyarakat sekitar, sehingga hal itu menyebabkan Wiro termotivasi untuk mengumpulkan fosil-fosil yang lain. Tujuan pengumpulan yang dilakukan Wiro hanya sebatas ingin melestarikan benda-benda peninggalan sejarah tersebut. Sedangkan penemuan fosil oleh masyarakat yang tidak sengaja atau secara kebetulan diberikan 
imbalan jasa misalnya berupa rokok maupun beras. Hal itu dilakukan dengan harapan bahwa nantinya fosil yang ditemukan tidak dijual kepada orang luar atau orang asing.

Bersumber dari gagasan Wiro yang ingin melestarikan fosil-fosil tersebut, sepertiga dari rumahnya terisi dengan koleksi fosil yang diletakkan di meja maupun di rak terbuka. Tetapi setelah ada peninjauan dari Depdiknas (Departemen Pendidikan Nasional)

Kabupaten Ngawi sekitar tahun 1978 Wiro mendapatkan bantuan 3 buah almari. Pada kurun waktu 1968 sampai 1978 fosil-fosil yang dilestarikan oleh Wirodihardjo masih berstatus koleksi pribadi. Baru pada tahun 1979 MUSKALA (Museum dan Purbakala) dari Kanwil Depdikbud (Kantor Wilayah Departemen Pendidikan dan Kebudayaan) Provinsi Jawa Timur mengadakan inventarisasi semua peninggalan sejarah purbakala dan menunjuk Wirodihardjo sebagai juru pelihara dengan status sebagai pegawai honorer. Pada tahun 1980/1981 Pemerintah Daerah mendirikan museum untuk menampung fosil-fosil tersebut. Kemudian pada tahun 1990/1991 mendapat bantuan dari APBD (Anggaran Pendapatan Belanja Daerah) Tingkat I Jawa Timur untuk merenovasi serta menambah sarana prasarana museum. Bertepatan dengan peringatan Seratus Tahun Pithecanthropus Erectus, pada tanggal 20 November 1991 Gubernur Jawa Timur Soelarso meresmikan museum tersebut dengan nama "Museum Trinil" sebagai bukti bahwa fosil-fosil yang ditemukan banyak yang berasal dari daerah Trinil. Selain itu, sebagai tanda jasa atas apa yang dilakukan oleh Wirodihardjo namanya diabadikan sebagai nama gedung pameran museum yaitu "Gedung Wirodihardjo" (PEMKAB DISPARIYAPURA, $2013: 16)$.

B. Data Kunjungan Wisatawan Museum Trinil Tahun 2010-2013 Museum Trinil merupakan salah satu tempat wisata edukasi yang ada di Kabupaten Ngawi dimana jumlah kunjungan wisatawan di Museum Trinil ini mulai meningkat pada tahun 2010 hingga 2013. Hal ini dapat dilihat 
dari tabel jumlah pengunjung

berikut :

Tabel 4.1

Tabel jumlah kunjungan wisatawan tahun 2009

\begin{tabular}{|l|c|c|c|c|c|}
\hline \multirow{2}{*}{$\begin{array}{c}\text { Tahun 2009, } \\
\text { Bulan }\end{array}$} & \multicolumn{4}{|c|}{ Jumlah Pengunjung } & \multirow{2}{*}{ Jumlah } \\
\cline { 2 - 5 } \multicolumn{1}{|c|}{1} & Umum & Asing & Dinas & Pelajar & \\
\hline Januari & 700 & 3 & 4 & 5 & 6 \\
\hline Februari & 412 & & & 514 & 1214 \\
\hline Maret & 758 & & & 218 & 630 \\
\hline April & 657 & 3 & & 104 & 862 \\
\hline Mei & 723 & & & 80 & 835 \\
\hline Juni & 735 & & & 140 & 803 \\
\hline Juli & 712 & & & 190 & 902 \\
\hline Agustus & 600 & & & 74 & 674 \\
\hline September & 525 & & & 82 & 607 \\
\hline Oktober & 559 & & & 344 & 903 \\
\hline November & 520 & 38 & & 148 & 706 \\
\hline Desember & 758 & & & 183 & 941 \\
\hline Jumlah & 7.659 & 41 & & 2.252 & $\mathbf{9 9 5 2}$ \\
\hline
\end{tabular}

Sumber : Data Loket Masuk Museum Trinil tahun 2009

Tabel 4.1 tentang jumlah

wisatawan tahun 2010 sampai 2013,

kunjungan wisatawan tahun 2009

yang terlihat pada tabel 4.2 sampai

tersebut sebagai pembanding

tabel 4.5 sebagai berikut:

dengan tabel jumlah kunjungan

Tabel 4.2

Tabel Jumlah Kunjungan Wisatawan Tahun 2010

\begin{tabular}{|l|c|c|c|c|c|}
\hline \multirow{2}{*}{$\begin{array}{c}\text { Tahun 2010, } \\
\text { Bulan }\end{array}$} & \multicolumn{4}{|c|}{ Jumlah Pengunjung } & \multirow{2}{*}{ Jumlah } \\
\cline { 2 - 5 } \multicolumn{1}{c|}{1} & Umum & Asing & Dinas & Pelajar & \\
\hline Januari & 546 & 3 & 4 & 5 & 6 \\
\hline Februari & 453 & & & 433 & 979 \\
\hline Maret & 456 & & & 61 & 577 \\
\hline April & 739 & & & 435 & 1174 \\
\hline Mei & 697 & & & 276 & 973 \\
\hline Juni & 275 & & & 278 & 553 \\
\hline Juli & 407 & & & 275 & 682 \\
\hline Agustus & 142 & 2 & & 22 & 166 \\
\hline & 2 & 3 & 4 & 5 & 6 \\
\hline September & 1319 & 27 & & 432 & 1778 \\
\hline Oktober & 580 & & 18 & 498 & 1096 \\
\hline November & 550 & 15 & & 541 & 1106 \\
\hline Desember & 585 & 1 & 6 & 350 & 942 \\
\hline \multicolumn{1}{|c|}{ Jumlah } & 6.749 & 45 & 24 & 3.725 & $\mathbf{1 0 . 5 4 3}$ \\
\hline
\end{tabular}

Sumber : Data Loket Masuk Museum Trinil Tahun 2010

Tabel 4.3 
Tabel Jumlah Kunjungan Wisatawan Tahun 2011

\begin{tabular}{|c|c|c|c|c|c|}
\hline \multirow{2}{*}{$\begin{array}{c}\text { Tahun 2011, } \\
\text { Bulan }\end{array}$} & \multicolumn{4}{|c|}{ Jumlah Pengunjung } & \multirow{2}{*}{ Jumlah } \\
\hline & Umum & Asing & Dinas & Pelajar & \\
\hline 1 & 2 & 3 & 4 & 5 & 6 \\
\hline Januari & 751 & & & & 751 \\
\hline Februari & 649 & & & & 649 \\
\hline Maret & 500 & & & & 500 \\
\hline April & 707 & & & & 707 \\
\hline Mei & 568 & & & 70 & 638 \\
\hline Juni & 565 & & & 122 & 687 \\
\hline Juli & 498 & & & 263 & 761 \\
\hline Agustus & 479 & & & 158 & 637 \\
\hline September & 546 & & & 145 & 691 \\
\hline Oktober & 586 & & 12 & 1754 & 2352 \\
\hline November & 535 & 3 & & 517 & 1055 \\
\hline Desember & 679 & & 25 & 682 & 1386 \\
\hline Jumlah & 7.063 & 3 & & 3.711 & 10.814 \\
\hline
\end{tabular}

Sumber : Data Loket Masuk Museum Trinil Tahun 2011

Tabel 4.4

Tabel Jumlah Kunjungan Wisatawan Tahun 2012

\begin{tabular}{|l|c|c|c|c|c|}
\hline \multirow{2}{*}{$\begin{array}{c}\text { Tahun 2012, } \\
\text { Bulan }\end{array}$} & \multicolumn{4}{|c|}{ Jumlah Pengunjung } & \multirow{2}{*}{ Jumlah } \\
\cline { 2 - 5 } & Umum & Asing & Dinas & Pelajar & \\
\hline Januari & 2 & 3 & 4 & 5 & 6 \\
\hline Februari & 602 & 21 & & 332 & 955 \\
\hline Maret & 535 & 12 & & 96 & 643 \\
\hline April & 735 & & & 267 & 1002 \\
\hline Mei & 700 & 2 & & 192 & 924 \\
\hline Juni & 989 & & & 518 & 1507 \\
\hline Juli & 697 & 25 & & 690 & 1412 \\
\hline Agustus & 458 & 19 & & 120 & 637 \\
\hline September & 581 & 20 & & 236 & 837 \\
\hline Oktober & 528 & 20 & & 290 & 847 \\
\hline November & 666 & 22 & & 703 & 1391 \\
\hline Desember & 990 & 10 & & 234 & 759 \\
\hline Jumlah & 7.880 & & & 694 & 1604 \\
\hline
\end{tabular}

Sumber : Data Loket Masuk Museum Trinil Tahun 2012

Tabel 4.5

Tabel Jumlah Kunjungan Wisatawan Tahun 2013

\begin{tabular}{|l|c|c|c|c|c|}
\hline \multirow{2}{*}{$\begin{array}{c}\text { Tahun 2013, } \\
\text { Bulan }\end{array}$} & \multicolumn{4}{|c|}{ Jumlah Pengunjung } & \multirow{2}{*}{ Jumlah } \\
\cline { 2 - 5 } & Umum & Asing & Dinas & Pelajar & \\
\hline Januari & 2 & 3 & 4 & 5 & 6 \\
\hline Februari & 580 & & & 198 & 778 \\
\hline Maret & 343 & & & 223 & 566 \\
\hline April & 552 & & 26 & 649 & 1227 \\
\hline Mei & 747 & 3 & 5 & 592 & 1347 \\
\hline
\end{tabular}




\begin{tabular}{|l|c|c|c|c|c|}
\hline Juni & 971 & & & 840 & 1811 \\
\hline Juli & 410 & 20 & & 92 & 522 \\
\hline Agustus & 760 & & & 263 & 1023 \\
\hline September & 494 & & 22 & 97 & 613 \\
\hline Oktober & 625 & 4 & 23 & 604 & 1256 \\
\hline 1 & 2 & 3 & 4 & 5 & 6 \\
\hline November & 530 & 5 & & 121 & 656 \\
\hline Desember & 1392 & & 75 & 1034 & 2501 \\
\hline Jumlah & 8.036 & 52 & 151 & & $\mathbf{1 3 . 5 4 0}$ \\
\hline
\end{tabular}

Sumber : Data Loket Masuk Museum Trinil Tahun 2013

Berdasarkan tabel di atas maka dapat dilihat bahwa dari tahun 2010 saampai tahun 2013 jumlah wisatawan yang berkunung ke Museum Trinil semakin meningkat.

\begin{tabular}{|llllll|} 
Hal & ini & dapat & dilihat & melalui & grafik \\
\hline & & & \\
\hline
\end{tabular}

Bagan 4.1

Perkembangan Jumlah Wisatawan Museum Trinil Tahun 2009-2010

\section{Temuan Penelitian Dampak Kunjungan Wisatawan Terhadap Pelestarian Museum Trinil}

Bedasarkan paparan data yang telah disampaikan di atas maka dapat dilihat bahwa dampak kunjungan wisatawan terhadap pelestarian Museum Trinil, terdapat dua dampak yang ditimbulkan yaitu dampak positif dan dampak negatif.

Dampak positif dari semakin meningkatnya jumlah wisatawan bahwa kondisi museum dapat dikatakan semakin lestari. Hal ini terbukti dari temuan-temuan yang ada di lapangan menunjukkan bahwa dampak positif dari 
peningkatan jumlah wisatawan yang terjadi pada tahun 2010 hingga 2013 yaitu dengan kondisi gedung Museum Trinil yang lebih bagus dan lebih nyaman bila dibandingkan dengan kondisi gedung sebelum tahun 2010. Kondisi demikian disebabkan karena adanya renovasi seluruh gedung Museum Trinil oleh Pemerintah Pusat yang dilakukan pada tahun 2013.

Selain itu, dengan meningkatnya jumlah wisatawan juga menjadikan banyak dibukanya warung kuliner yang ada disekitar Museum Trinil. Meskipun warung kuliner banyak berdiri di sekitar Museum Trinil, pada kenyataannya hanya terdapat satu atau dua saja yang membuka untuk berjualan kuliner. Untuk kios-kios yang sudah disediakan oleh pihak museum sebagai tempat berjualan souvenir sampai saat ini masih kosong dan tidak ada yang pernah berjualan disitu. Berdasarkan paparan data dan hasil pengamatan warungwarung kuliner dan kios-kios souvenir buka hanya pada saat tertentu saja. Contohnya pada saat ada lomba dalang dan sinden cilik Tingkat Sekolah Dasar Se-Kabupaten Ngawi.

Selain itu, bagi pemerintah setempat tentu akan menambah pemasukan dana APBD (Anggaran Pendapatan Belanja Daerah). Meskipun Museum Trinil dalam hal berpatisipati untuk pemasukan dana APBN dapat dikatakan jauh dibawah rata-rata, tetapi setidaknya dengan semakin bertambahnya jumlah wisatawan maka hal itu juga akan menambah dana APBD yang masuk ke Pemerintah Kabupaten Ngawi.

$$
\text { Sedangkan temuan }
$$

dilapangan yang menunjukkan dampak negatif dengan semakin meningkatnya jumlah wisatawan di Museum Trinil maka kondisi Museum Trinil juga dapat dikategorikan semakin tidak lestari. Kondisi ini terbukti dengan banyaknya sampah yang tertinggal di taman belakang gedung Museum Trinil. Selain itu, lebih parah lagi banyaknya coretan di replika hewan purba yang juga terletak di taman belakang. Hal tersebut dikarenakan letak taman belakang jauh dari pengawasan para pengelola museum, sehingga bagi wisatawanwisatawan yang kurang memiliki kesadaran akan menjaga dan melestarikan tempat wisata mengotori dan merusak bendabenda yang ada disekitarnya.

Tidak hanya coretan yang ada direplika hewan purba di taman 
belakang saja, tetapi tugu peresmian berdirinya Museum Trinil yang terletak di taman samping bersebelahan dengan gedung pameran Museum Trinil juga banyak terdapat coretan. Tetapi bedanya taman sekitar gedung pameran dan pendopo tidak terdapat sampah yang bertebaran, lebih terjaga kebersihannya dan lebih terawat.

Berdasarkan kondisi yang ada di lapangan, maka semakin meningkatnya jumlah wisatawan yang ada di Museum Trinil dapat dikatakan kondisi Museum Trinil akan menjadi lebih buruk atau tidak lestari. Hal ini didukung dengan beberapa bukti yang ada dilapangan menyebutkan meskipun gedung Museum Trinil sudah lebih bagus dan nyaman, tetapi dampak negatif dari tahun ke tahun belum tentu dapat dicegah. Sebab kesadaran wisatawan untuk menjaga kebersihan dan melestarikan tempat wisata bisa jadi juga akan semakin berkurang apabila tidak diimbangi dengan managemen pengelolaan museum yang baik.

\section{Pembahasan}

Dampak kunjungan wisatawan terhadap pelestarian Museum Trinil yang terjadi pada tahun 2010 sampai tahun 2013 yaitu :

\section{A. Dampak Positif Kunjungan Wisatawan Terhadap Pelestarian Museum Trinil}

Setiap wisatawan yang
berkunjung ke Museum Trinil memiliki
tujuan yang berbeda-beda diantaranya
tujuan edukasi maupun tujuan rekreasi
yang hanya sekedar melepas penat
yang ada dalam diri masing-masing
wisatawan dan untuk mengetahui suatu
objek wisata yang belum pernah
dikunjunginya. Hal ini relevan dengan
maksud berwisata menurut I Gde
Pitana dan Gayatri (2005: 47) yaitu
aktivitas bersantai atau aktivitas waktu
luang bukanlah suatu aktifitas
kewajiban dan umumnya dilakukan
pada saat seseorang bebas dari
pekerjaan.

Tahun 2010 Musuem Trinil mulai ramai kembali dikunjungi oleh wisatawan, baik wisatawan lokal maupun wisatawan interlokal, baik wiisatwan dalam negeri maupun wisatawan luar negeri. Peningkatan jumlah wisatawan yang terjadi pada tahun 2010 tersebut dilatarbelakangi karena adanya Kebijakan Pemerintah Daerah tentang Wajib Kunjung Museum yang diperuntukkan bagi seluruh anak sekolah Se-Kabupaten Ngawi khususnya anak sekolah dasar. Hal tersebut merupakan salah satu strategi yang dicanangkan oleh Pemerintah 
Kabuapten Ngawi sebagai bentuk upaya pelestarian Museum Trinil. Selain itu, upaya lain yang dilakukan Pemkab yaitu dengan diadakannya lomba dalang dan sinden cilik tingakaT SD SeKabuapten Ngawi yang diselenggaran oleh Dinas Pendidikan dan Kebudayaan Kabupaten Ngawi bertempat di pendopo Museum Trinil. Dinas Pariwisata Kabupaten Ngawi mengungkapkan bahwa kedua strategi yang dicanangkan Pemerintah Kabupaten Ngawi tersebut dirasa cukup efektif untuk menjadikan Museum Trinil ramai akan pengunjung dan menjadikan Museum Trinil semakin dikenal oleh masyarakat luas.

\begin{tabular}{ccc}
\multicolumn{2}{c}{ Meningkatnya } & jumlah \\
wisatawan & Museum Trinil sampa
\end{tabular}
tahun 2013 tersebut memberikan dampak positif bagi Museum Trinil maupun bagi masyarakat sekitar Museum Trinil. Hal ini terbukti dari warung-warung makan yang berdiri di sekitar Museum Trinil semakin menjamur. Tetapi, ada fakta lain yang menyebutkan bahwa meskipun warung-warung makan banyak berdiri disana, warung-warung makan tersebut hanya buka pada saat-saat tertentu saja, seperti pada saat ada perlombaan maupun pada saat liburan panjang anak sekolah. Sehingga tidak setiap hari semua warunng yang ada di sekitar
Museum Trinil itu buka untuk berjualan.

$\begin{array}{lcc} & \text { Jumlah wisatawan di } \\ \text { Museum } & \text { Trinil yang semakin } \\ \text { meningkat dari tahun } 2010 \text { hingga }\end{array}$
2013 dapat menjadikan Museum Trinil saat ini dapat dikatakan bertambah lestari daripada tahun sebelumnya. Hal ini terbukti dengan adanya pemugaran gedung Museum Trinil yang dilakukan oleh Pemerintah Pusat pada tahun 2013. Dimana gedung-gedung Museum Trinil yang terdiri dari gedung pameran, kantor, taman, laboratorium dan pendopo dilakukan pemugaran meskipun bukan pemugaran secara total. Pemugaran tersebut guna memperbaiki fasilitas-fasilitas di Museum Trinil seperti gedung pameran Museum Trinil sebelum dipugar dalam kondisi yang tergolong memprihatinkan untuk dikategorikan sebagai sebuah gedung pameran, atap yang sebagian besar dalam keadaan bocor serta lantai dengan kondisi yang kurang bersih.

\section{B. Dampak Negatif Kunjungan Wisatawan Terhadap Pelestarian Museum Trinil}

Keinginan wisatawan yang seharusnya menganggap bahwa benda purbakala merupakan benda peninggalan sejarah yang harus di jaga kelestariannya guna mengetahui 
kehidupan masa lalu tidak relevan dengan teori yang diungkapkan oleh Oka A.Yoeti (2006:6) tentang alasan keberadaan benda-benda peninggalan sejarah dan purbakala yang dianggap menarik serta diminati oleh wisatawan mungkin dulu ikut terlibat dalam perjalanan sejarah atau termasuk anak cucu yang ingin menapaki tilas leluhur mereka. Hal ini terbukti dari alasan sebagian besar wisatawan yang berkunjung ke Museum Trinil hanya untuk berekreasi, sebagian kecil baru datnag dengan alasan edukasi. Misalnya wisatawan asing yang datang ke Museum Trinil mayoritas untuk kepentingan penelitian. Khususnya wisatawan asal Belanda dan Perancis yang lebih banyak melakukan kunjungan ke Museum Trinil datang dengan tujuan penelitian lapangan seperti penggalian fosil-fosil purba yang ada di sekitar Museum Trinil.

Penggalian fosil yang
dlakukan oleh wisatawan asing
berdampak pada hasil fosil yang
ditemukan bisa jadi akan dibawa ke
Belanda untuk dipadukan dengan hasil
temuan fosil yang dulu dilakukan oleh
Eugene Dubois penemu fosil Pithecanthropus Erectus. Hal ini menyebabkan koleksi-koleksi yang ada di Museum Trinil sebagian replika dari bentuk asli fosil yang telah dibawa ke
Leiden Belanda. Dengan begitu benda purbakala yang ada di Indonesia khususnya di Museum Trinil menjadi berkurang keasliannya. Hal ini didukung dengan teori yang dikemukan oleh Murdyastomo dan Sudjiman (1996: 15) bahwa keinginan untuk membawa benda asli, bukan cindera mata tiruan yang dibuat menyerupai benda aslinya menimbulkan jual beli benda antik yang mungkin dari sekian banyak perdagangan salah satunya adalah benda-benda peninggalan sejarah dan purbakala.

Meskipun demikian koleksi yang tersimpan dalam museum, selain untuk penyelamatan maupun objek penelitian kepurbakalaan atau arkeologis, juga berfungsi untuk memperkenalkan peninggalanpeninggalan budaya Indonesia (Iskandar, 2009: 103). Museum Trinil yang berdiri secara resmi sejak tahun 1990 di bawah pengawasan dan pengelolan Pemerintah Kabupaten Ngawi dan Badan Pelestarian Cagar Budaya Trowulan Mojokerja sampai saat ini telah menunjukkan eksistensinya menjadi sebuah museum yang berfungsi sebagaimana mestinya sebagai museum khusus yang memiliki koleksi benda-benda purbakala khususnya fosil manusia purba Pithecanthropus Erectus yang menjadi 
salah satu tempat penelitian kepurbakalaan dan juga tujuan wisata edukasi yang memperkenalkan kehidupan masa lalu, artinya Museum Trinil sebagai jembatan penghubung antara masa lalu dengan masa sekarang.

Menurut Murphy (dalam I Gde Pitana dan Gayatri, 2005: 53) tipologi wisatawan pada prinsipnya diklasifikasikan ke dalam dua jenis yaitu tipologi wisatawan atas dasar interaksi (interactional type) dan atas dasar kognitif-normatif. Tipologi atas dasar interaksi dilihat dari seberapa jauh interaksi antara wisatawan dengan masyarakat lokal, Sedangkan tipologi atas dasar kognitif-normatif menekankan pada motivasi yang melatarbelakangi perjalanan. Oka A.Yoeti (1994: 7) merumuskan motivasi wisatawan melakukan perjalanan wisata diantaranya untuk tujuan santai dan kesegaran badan, tujuan kesehatan, mencari kesenangan, menaruh perhatian terhadap Negara lain, alasan untuk mengunjungi famili, untuk mencari hal-hal yang bersifat spiritual, dan keinginan untuk mengetahui lebih mendalam tata cara hidup di tempat yang dikunjunginya

Interaksi antar wisatawan dan masyarakat lokal hanya sekedar bertegur sapa. Masyarakat bisa menerima kedatangan wisatawan dengan tepo sliro atau diterima dengan baik, tetapi ketika wisatawan melanggar peraturan yang dibuat oleh pihak museum, masyarakat hanya mampu mengingatkan sewajarnya atau bahkan tidak perduli. Sedangkan motivasi yang melatarbelakangi perjalanan wisatawan di Museum Trinil hanya sekedar mencari kesenangan dan juga keinginan untuk mengetahui lebih mendalam tata cara hidup di tempat yang dikunjunginya. Mencari kesenangan dalam hal ini antara wisatawan anak-anak, wisatawan remaja dan wisatawan dewasa satu dengan yang lainnya berbeda-beda. Bagi wisatawan anak-anak datang ke Museum Trinil mayoritas ajakan dari keluarga, ingin bermain di taman dan karena wajib kunjung museum. Wisatawan remaja yang berkunjung mayoritas untuk berjalan-jalan dengan lawan jenis, sedangkan wisatawan dewasa berkunjung ke Museum Trinil untuk mengenalkan Museum Trinil pada keluarganya.

Berdasarkarkan data yang peroleh di lapangan tahun 2010 sampai 2013 jumlah wisatawan semakin meningkat dengan rata-rata wisatawan yang berkunjung ke Museum Trinil berkisar 15 sampai 20 wisatawan untuk hari biasa dan mencapai 30 
wisatawan untuk hari libur baik dari wisatawan lokal maupun mancanegara. Peningkatan yang terjadi pada tahun 2010 sampai tahun 2013 tersebut menjadikan Museum Trinil dapat dikatakan semakin tidak lestari. Hal ini terbukti dari paparan yang telah disampaikan di atas bahwa dampak dari banyaknya wisatawan asing yang datang ke Museum Trinil mayoritas memiliki keinginan untuk membawa benda atau fosil asli temuan penggalian mereka di lapangan.

Selain itu, tidak hanya wisatawan asing yang memberikan dampak negatif pada pelestarian Museum Trinil tetapi meningkatnya wisatawan lokal yang melakukan kunjungan ke Museum Trinil menjadikan Museum Trinil juga semakin tidak lestari. Menurut temuan penelitian di lapangan, fakta tersebut dibuktikan dengan banyaknya sampah yang ditinggalkan oleh sebagian besar wisatawan lokal di berbagai tempat khususnya tempat-tempat yang jauh dari pengawasan pengelola museum. Tempat-tempat tersebut diantaranya taman belakang Museum Trinil dan taman samping gedung pameran. Di taman belakang museum selain banyak sampah yang tertinggal, juga banyak coretan-coretan menggunakan aerosol semprot baik pada dinding maupun pada replika hewan purba.

Jauhnya lokasi taman dari pengawasan pengelola Museum Trinil seharusnya bukan menjadi alasan wisatawan berbuat hal-hal yang merusak benda-benda di sekitar Museum Trinil. Menurut Oka A.Yoeti (2006: 14), terdapat dua fungsi museum yaitu pertama melindungi dan menjaga kelestarian benda-benda bukti material hasil budaya manusia serta alam dan lingkungannya. Kedua, mengkomunikasikan dan menyebarkan informasi mengenai benda-benda tersebut kepada masyarakat melalui publikasi, bimbingan edukatif cultural dan pameran.

Fungsi Museum Trinil untuk mengkomunikasikan benda-benda cagar budaya berupa benda kepurbakalaan dilakukan dengan cara pembuatan leaflet baik dari Pemerintah Kabupaten Ngawi maupun dari Museum Trinil itu sendiri disamping diadakan pameran pada acara khusus diluar Museum Trinil itu sendiri. Selain itu, Museum Trinil juga sudah menjalankan fungsinya untuk melindungi dan menjaga kelestarian benda-benda cagar budaya berupa benda purbakala tetapi kurangnya rasa peka pada masing-masing wisatawan menjadi faktor penentu utama dalam 
menjaga dan melestarikan Museum Trinil sebagai tempat pelestarian benda cagar budaya tersebut. Meskipun secara fisik gedung dan bangunan yang ada di Museum Trinil mengalami kemajuan, apabila semua sikap wisatawan yang berkunjung kesana memiliki sikap untuk merusak maka dapat dipastikan pelestarian Museum Trinil tidak akan berjalan dengan baik atau bahkan mengalami kegagalan.

Berdasarkan paparan dan pembahasan yang telah diuraikan di atas, maka solusi yang diberikan untuk meminimalisir dampak negatif yang muncul akibat meningkatnya jumlah wisatawan yang berkunjung ke Museum Trinil yaitu dengan diadakannya peraturan yang jelas untuk para wisatawan baik lokal maupun wisatawan asing, baik jelas dalam pensosialisasiannya maupun sanksi tegas yang akan diterima wisatawan apabila peraturan tersebut dilanggar. Meskipun solusi tersebut nantinya akan memberikan dampak lain bagi Museum Trinil misalnya jumlah wisatawan yang berkunjung akan berkurang, tetapi setidaknya wisatawan yang berkunjung untuk kedepannya akan mulai terbiasa dengan peraturan tersebut. Tentu dalam pensosialisasian peraturan tersebut dibuat dengan maksud mengajak wisatawan dan masyarakat luas untuk menjaga dan melestarikan tempat-tempat wisata khususnya tempat wisata cagar budaya.

Harapannya Museum Trinil yang berdiri saat ini dapat lebih diperhatikan khususnya Dinas Pariwisata Pemuda dan Olahraga Kabupaten Ngawi sebagai tujuan wisata edukasi dan tempat pelestarian benda cagar budaya. Meskipun Museum Trinil juga bagian dari BPCB (Badan Pelestarian Cagar Budaya) Trowulan, bukan berarti semua tanggung jawab pelestarian hanya bertumpu pada pengelola dan BPCB Trowulan. Selain itu Pemerintah Kabupaten seharusnya tidak hanya berhenti pada renovasi yang dilakukan pada tahun 2013 akan sarana-prasarana penunjang di sekitar Museum Trinil saja tetapi juga sarana prasarana penunjang lainnya seperti jalan menuju lokasi Museum Trinil dan alat transportasi dapat diperhatikan.

\section{Penutup}

\section{A. Simpulan}

Berdasarkan paparan data, temuan penelitian dan pembahasan yang telah disampaikan dimuka maka dapat disimpulkan bahwa dampak yang ditimbulkan dengan adanya kunjungan wisatawan di Museum Trinil yaitu semakin 
meningkatnya jumlah wisatawan yang datang maka Museum Trinil semakin tidak lestari. Hal ini dibuktikan oleh sikap atau perilaku yang dibawa oleh masing-masing wisatawan baik wisatawan asing maupun wisatawan lokal memberikan banyak kerusakan pada Museum Trinil. Dampak yang diberikan wisatawan asing yaitu keinginan dari sebagian besar wisatawan asing untuk memiliki benda-benda cagar budaya yang asli bukan replika buatan manusia sebagai sebuah souvenir. Sehingga hal ini menyebabkan sebagian besar koleksi-koleksi yang ada di Museum Trinil hanya sebuah replika atau tiruan dari fosil yang sebenarnya yang dapat mengurangi keaslian bukti peninggalan sejarah yang ada Kabupaten Ngawi khususnya di Museum Trinil itu sendiri.

Sedangkan dampak yang ditimbulkan dari wisatawan lokal antara lain sampah-sampah yang ditinggalkan semakin banyak. Kurangnya kesadaran atau bahkan tidak adanya kesadaran dari masingmasing wisatawan untuk menjaga kebersihan di Museum Trinil khususnya tempat-tempat yang lokasinya jauh dari pengawasan pengelola. Selain itu, kurangnya kepedulian untuk mengingatkan antara wisatawan satu dengan wistawan yang lainnya dalam menjaga kebersihan lingkungan. Selain itu, sikap tidak bertanggung jawab dari para wisatawan lokal untuk melakukan aksi coret-coret pada benda-benda yang ada di sekitar Museum Trinil. Terbukti dari banyaknya coretan pada replika hewan-hewan purba yang ada di taman belakang gedung serta pada tugu peresmian berdirinya Museum Trinil.

Meskipun peningkatan jumlah wisatawan yang terjadi mulai tahun 2010 hingga 2013 membawa dampak positif dengan perenovasian gedung Museum Trinil yang dilakaukan oleh Pemerintah Pusat, dampak negatif akan tetap ada dan kemungkinan juga akan merusak hasil perenovasian tersebut apabila tidak diimbangi dengan peraturan-peratuan yang jelas untuk para wisatawan baik asing maupun lokal.

\section{B. Saran}

Setelah melakukan peneliitian ini, sebagai peneliti dan insan akademisi ada beberapa hal yang menjadi saran antara lain:

1. Pengelola Museum Trinil

Perenovasian gedung Museum Trinil yang dilakukan 
pada tahun 2013 hendaknya bukan suatu akhir perjalanan para pengelola museum menunjukkan keberhasilannya dalam pelestarian Museum Trinil, tetapi hal tersebut menjadi awal dari perjalanan pengelola untuk memanagement kembali agar Museum Trinil yang dulu jarang dikenal masyarakat luas tidak terulang kembali. Sebaiknya dengan kondisi bangunan yang lebih baik saat ini, seluruh pengelola Museum Trinil lebih maksimal lagi dalam menjaga dan melestarikan Museum Trinil melalui peraturanperaturan yang jelas khususnya bagi wisatawan.

\section{Pemerintah Kabupaten Ngawi}

$$
\begin{aligned}
& \text { Peneliti menaruh } \\
& \text { harapan yang besar bagi } \\
& \text { Pemerintah Kabupaten Ngawi } \\
& \text { untuk lebih memperhatikan dan } \\
& \text { mempedulikan keberadaan } \\
& \text { Museum Trinil sebagai salah } \\
& \text { satu tempat wisata edukasi dan } \\
& \text { pelestari benda peninggalan } \\
& \text { bersejarah demi kemajuan ilmu } \\
& \text { pengetahuan. Selain itu, } \\
& \text { diharapkan kelengkapan dalam } \\
& \text { sarana prasarana berupa } \\
& \text { transportasi dan perbaikan } \\
& \text { jalan menuju lokasi Museum }
\end{aligned}
$$

$$
\begin{aligned}
& \text { Trinil dapat diperbaiki guna } \\
& \text { memperlancar serta } \\
& \text { mempermudah para wisatawan } \\
& \text { yang tidak menggunakan } \\
& \text { kendaraan pribadi. }
\end{aligned}
$$

\section{Wisatawan}

Peneliti berharap pada wisatawan baik wisatawan lokal maupun wisatawan asing di Museum Trinil untuk lebih menyadari bahwa semua yang ada di tempat wisata harus dijaga dan dilestarikan baik dari segi lingkungannya maupun koleksi yang ada di Museum Trinil. Sebab menjaga dan menlestarikan bukan hanya kewajiban dari pengelola Museum Trinil saja tetapi juga semua yang terlibat dalam lingkungan tersebut baik wisatawan maupun warga sekitar.

\section{DAFTAR PUSTAKA}

Abraham Nurcahyo. 2011. Jurnal Agastya Pendidikan Sejarah. Madiun: Program Studi Pendidikan Sejarah IKIP PGRI Madiun

dan Yudi Hartono. 2011. Konsep Dasar dan Pengembangan IPSSD. Magetan: Swastika Press

Basrowi dan Suwandi. 2008. Memahami Penelitian Kualitatif. Jakarta: Rineka Cipta 
Burhan Bungin. 2007. Penelitian Kualitatif: Komunikasi, Ekonomi. Kebijakan Publik dan Ilmu Sosil Lainnya. Jakarta: Kencana Prenada Media Group

Ensiklopedia Nasional Indonesia. 1990. Jakarta: PT Cipta Adi Pustaka

Gabriel Amin. 2003. Metodologi Penelitian dan Studi Kasus. Sidoarjo: Citra Media

Gamal Suwantoro. 2004. Dasar-dasar Pariwisata. Yogyakarta: CV ANDI Offset

Hadari Nawawi. 2005. Metode Penelitian Bidang Sosial. Yogyakarta: Gadjah Mada University Press

H.B Sutopo. 2006. Metode Penelitian Kualitatif Dasar teori Dan Terapan Dalam Penelitian. Surakarta: Universitas Sebelas Maret

Husaini Usman. 2004. Metodologi Penelitian Sosial. Jakarta: Bumi Aksara

Husein Umar. 2011. Metode Penelitian Untuk Skripsi dan Tesisi Bisnis Edisi Kedua. Jakarta: PT RajaGarafindo Persada

I Gde Pitana dan Gayatri. 2005. Sosiologi Pariwisata. Yogyakarta: ANDI Offset dan Diarta. 2009. Pengantar Ilmu Pariwisata. Yogyakarta: CV ANDI Offset

I Gusti Bagus dan Mahadewi. 2010. Metodologi Penelitian Pariwisata dan Perhotelan. Yogyakarta: CV ANDI Offset

I Made Wirartha. 2006. Metodologi Penelitian Sosiologi. Yogyakarta: Andi Yogyakarta

Irna Trilestari. 2012. Jurnal Penelitian dan Pengembangan Kebudayaan Vol.7 No.2 . Jakarta: Puslitbang Kebudayaan Komp. Kemendikbud
Joko Subagyo. 2004. Metode Penelitian dalam Teori Dan Praktek. Jakarta: Rineka Cipta

Kodhyat. 1996. Sejarah Pariwisata dan Perkembangannya di Indonesia. Jakarta: Grasindo

Kunjungi Museum Jamu. 2013. 3 Juli. Kompas

Lexy J.Moleong. 2011. Metodologi Penelitian Kualitatif Edisi Revisi. Bandung: PT Remaja Rosdakarya

Miles, Mathew B dan A Michael Hubbermain. 1992. Analisis Data Kualitatif: Buku Sumber Tentang Metode-Metode Baru. Jakarta: UI Press

Muljadi. 2010. Kepariwisataan dan Perjalanan. Jakarta: PT Raja Garfindo Persada

Murdyastomo dan Sudjiman. 1996. Dampak Pariwisata Terhadap Pelestarian Benda Sejarah dan Purbakala. Jurnal Informasi: Kajian Masalah Pendidikan dan Sosial (Online), No. 3 Th XXIV, (www.staff.uny.ac.id Diunduh 29 Maret 2014)

Moehar Daniel. 2003. Metode Penelitian Sosial Ekonomi: Dilengkapi Beberapa Alat Analisa dan Penunun Penggunaan. Jakarta: PT Bumi Aksara

Mohammad Iskandar. 2009. Sejarah Kebudayaan Indonesia. Jakarta: PR Raja Grafindo Persada

Nana Syaodih. 2011. Metode Penelitian Pendidikan. Bandung: PT Remaja Rosdakarya

Nyoman S. Pendit. 2006. Ilmu Pariwisata Sebuah Pengantar Perdana. Jakarta: PT Pradnya Paramita

Oka A. Yoeti. 2006. Pariwisata Budaya dan Solusinya. Jakarta: PT Pradnya Paramita 


\begin{tabular}{c} 
1996. Pengantar Ilmu \\
\hline Pariwisata. Bandung: Angkasa \\
1994. Komersialisasi Seni Budaya \\
Dalam Pariwisata. \\
Bandung: Angkasa
\end{tabular}

Poerwadarminta. 2007. Kamus Umum Bahasa Indonesia Edisi Ketiga. Jakarta: Balai Pustaka

Soenatris Hadi. 2001. Situs Museum Trinil Kabupaten Ngawi

Sugiyono. 2006. Metode Penelitian Pendidikan: Pendekatan Kuantitatif, Kualitatif, dan R\&D. Bandung: Alfabeta

. 2013. Metode Penelitian Pendidikan: Pendekatan Kuantitatif, Kualitatif, dan R\&D. Bandung: Alfabeta

Supratikno Raharjo. 2011. Pengelolaan Warisan Budaya Dalam Pariwisata. Bandung: Lubuk Agung

Urip Suroso. 1993. Kecil Tapi Indah: Pedoman Pendirian Museum. Jakarta: Departemen Pendidikan dan
Kebudayaan Direktorat Jenderal Kebudayaan Proyek Pembinaan Permuseuman

Wahidmurni. 2008. Cara Mudah Menulis Proposal dan Laporan Penelitian. Malang: Universitas Negeri Malang Press

\section{Arsip}

Pemerintah Kabuapten Ngawi. 2013. Buku Pariwisata dan Sejarah. Ngawi: Dinas Pariwisata Kebudayaan Pemuda dan Olahraga Kabupaten Ngawi

Peraturan Pemerintah No.19 Tahun 1995 Tentang Pemeliharaan dan Pemanfaatan Benda Cagar Budaya di Museum pasal 1 ayat 1

Undang-Undang Republik Indonesia No.10 Tahun 2009 Tentang Kepariwisataan

Undang-Undang Republik Indonesia Nomor 11 Tahun 2010 Tentang Cagar Budaya. 2010. Mojokerto: Balai Pelestarian Peninggalan Purbakala Trowulan 